〈平成11年度日本茶業技術協会技術賞受賞研究〉 茶樹の枝条活力と整せん枝に関する研究

\author{
長崎県総合農林試験場東彼杵茶業支場* \\ 森山新三郎** \\ (平成13年 9 月 3 日受理)
}

\title{
Studies on the Vitality of Shoot and the Technique of Skiffing and Pruning on Tea Plant
}

\author{
Shinzaburo MORIYAMA \\ Higashisonogi Tea Branch Nagasaki Prefectural Agriculture and Forestry Experiment \\ Station
}

\section{1 はじめに}

茶園の樹高は年次の経過とともに高くな り，摘採・整枝を繰り返すことで枝条が細ま り，生葉収量も次第に減少する。このため, 土壤改良や肥培管理とともに更新や整せん枝 等の技術によって, 茶品質や生産力の維持・ 向上が必要である。三番茶の摘採中止は, 一 般的に価格調整や枝条活力の回復・向上を目 的として行われている。摘採の中止は秋芽を 繁茂し，樹勢を回復させる。しかし，茶園に よっては過繁茂となり枝条が不揃いのため, 秋整枝作業が困難なばかりでなく，芽数を確 保するため整枝位置が低くなりやすい。その 結果として発芽力の弱い枝条部位での整枝と なって，樹勢が良くても翌年の一番茶は生葉 収量が上がらず，茶品質の劣る場面が多く見 られる。秋芽の過繁茂は翌年一番茶の生葉収 量・茶品質を低下させることについては，田 中1) $(1992)$, 中野ら ${ }^{2)}(1997)$ が報告している。

ここでは, 更新経歴の違いによる母枝の形
状と新芽の発芽力, 更新処理後の新芽の再生 数や再生芽の仕立て, 更新効果の持続年数, 三番茶芽の処理による翌年一番茶への影響等 について，これまで行った試験 ${ }^{3 \sim 6)}$ (1984〜 1996）をまとめた。

試験地の長崎県総合農林試験場東彼杵茶業 支場は, 標高 $380 \mathrm{~m}$, 年平均気温 $13.8^{\circ} \mathrm{C}$, 年間 降水量約 $2,500 \mathrm{~mm}$, 土㙵は玄武岩を母材とす る造成地で細粒赤土〜黄色土, 年間10a当た り $\mathrm{N}-75 \mathrm{~kg}, \mathrm{P}_{2} \mathrm{O}_{5}-38 \mathrm{~kg}, \mathrm{~K}_{2} \mathrm{O}-38 \mathrm{~kg}$, 堆 廐肥 $2,000 \mathrm{~kg}$ を毎年投入している茶園で, 品 種は‘やぶきた’を用いた。なお, 試験期間中に 霜害や干ばつの影響はあった。

\section{2 母枝の形状と新芽再生力 ${ }^{3)}$}

2. 1 更新後の経過年数と秋枝の形状およ び翌年一番茶の収量

樹龄 22 年生で, 再中切り更新 2 年樹と更新 7 年樹の秋整枝後の樹冠面は, 2 年樹の秋枝 数は少ないが,枝条は大きく,整枝率も高かっ た。このことは秋芽が十分伸びていたことが

• テ853-0007 長崎県福江市福江町 14-1

現：長崎県五島農業改良普及センター 


\begin{tabular}{|c|c|c|c|c|c|c|c|c|}
\hline \multirow[b]{2}{*}{$\begin{array}{l}\text { 中切り更新後 } \\
\text { の経過年数 }\end{array}$} & \multirow[b]{2}{*}{$\begin{array}{c}\text { 秋枝数 } \\
\left(1 \mathrm{~m}^{2} \text { 当たり) }\right.\end{array}$} & \multirow[b]{2}{*}{$\begin{array}{c}\text { 整枝率 } \\
(\%)\end{array}$} & \multirow[b]{2}{*}{$\begin{array}{c}\text { 茎の太さ } \\
(\mathrm{mm})\end{array}$} & \multirow[b]{2}{*}{$\begin{array}{l}\text { 節間長 } \\
(\mathrm{cm})\end{array}$} & \multirow{2}{*}{ 節問数 } & \multirow[b]{2}{*}{$\begin{array}{c}\text { 茥の緑色部 } \\
(\mathrm{cm})\end{array}$} & \multicolumn{2}{|c|}{ 葉の大きさ } \\
\hline & & & & & & & $\begin{array}{l}\text { 葉 幅 } \\
(\mathrm{cm})\end{array}$ & $\begin{array}{l}\text { 葉 長 } \\
(\mathrm{cm})\end{array}$ \\
\hline 中切り 2 年樹 & 1,018 & 46.2 & 1.7 & 1.8 & 1.7 & 1.0 & 2.5 & 5.8 \\
\hline 中切り 7 年樹 & 2,443 & 9.6 & 1.4 & 0.6 & 2.4 & 0.7 & 1.6 & 3.8 \\
\hline 有 意 性 & & $* *$ & $*$ & $* *$ & $*$ & $*$ & $* *$ & $* *$ \\
\hline
\end{tabular}

注）調査：1996年 1 月

有意性の検定：最小有意差法で行った。 **（1％） *（5\%）

秋枝数：秋整枝面上 $20 \mathrm{~cm} \times 20 \mathrm{~cm}$ 枠内についての枝数

整枝率 $=\frac{\text { 切除された枝数 }}{\text { 全秋枝数 }} \times 100$

荎の太さ：秋整枝で切れた枝＝最上葉から上位第 2 葉までの節問中央部

"n 切れなかった枝=芽の先端から第 2 葉と第 3 葉の節間中央部

節間長：秋整枝で切れなかった枝＝最上葉から上位第 2 葉までの節間長

” 切れなかった枝=第 2 葉と第 3 葉の節間長

節間数 : 2 葉以上着葉した枝の節問数

茎の緑色部：整枝で切れた枝は秋整枝面から，切れなかった枝は頂芽からの緑色部

葉の大きさ：1調査枝の健全葉で, 最も大きい葉の幅と長さ

表 2 中切り更新後の経過と一番茶および新芽除去後の生育・生葉収量

$(n=3)$

\begin{tabular}{|c|c|c|c|c|c|c|c|c|c|c|}
\hline \multicolumn{2}{|l|}{ 区別 } & & & & & & & & & \\
\hline $\begin{array}{c}\text { 中切り更新後 } \\
\text { の経過年数 }\end{array}$ & $\begin{array}{l}\text { 新芽 } \\
\text { 除去 }\end{array}$ & $\begin{array}{l}\text { 一番茶 } \\
\text { 萌芽期 }\end{array}$ & & $\begin{array}{c}\text { 調查日 } \\
\text { (摘採日) }\end{array}$ & $\begin{array}{c}\text { 新牙長 } \\
(\mathrm{cm})\end{array}$ & $\begin{array}{l}\text { 枼数 } \\
\text { (枚) }\end{array}$ & $\begin{array}{c}\text { 白芽重 } \\
(\mathrm{g})\end{array}$ & $\begin{array}{l}\text { 新芽数 } \\
\left(\text { 本 } / \mathrm{m}^{2}\right)\end{array}$ & $\begin{array}{c}\text { 出開度 } \\
(\%)\end{array}$ & $\begin{array}{l}\text { 生染収量 } \\
\left(\mathrm{g} / \mathrm{m}^{2}\right)\end{array}$ \\
\hline 中切り 2 年樹 & 処 理 & 4 月12日 & 4 月17日 & 6 月 9 日 & 5.5 & 3.0 & $57.9^{* *}$ & $1,617^{* *}$ & 24.7 & $933^{* *}$ \\
\hline 中切り 2 年樹 & 無処理 & 11 & - & 5 月10日 & 6.1 & 3.1 & $60.3^{*}$ & $1,408^{*}$ & 49.8 & 841 \\
\hline 中切り 7 年樹 & 処 理 & 4 月17日 & 4 月21日 & 6 月 6 日 & 2.8 & 2.4 & 38.6 & 742 & 39.6 & 301 \\
\hline 中切り 7 年樹 & 無処理 & $m$ & - & 5 月 10 日 & 4.3 & 3.6 & 42.8 & 1,800 & 40.4 & 681 \\
\hline
\end{tabular}

注）調查年：1996年

処理方法：一番茶萌芽期直後に新芽除去, その後再生した芽を調查

有意性の検定：処理·無処理ごとに中切り 2 年樹と 7 年樹の検定を最小有意差法で行った。** $(1 \%)$ $*(5 \%)$

示唆される。7 年樹の秋枝数は多いが整枝率 が低く，葉は小さかった（表 1 )。

2 年樹の一番茶は, 生葉の形状が大きく収 量が多かった。7 年樹の一番茶の百芽重はや や軽いが新芽数は多く, 生葉収量が多かった (表 2 )。

2.2 更新後経過年数の異なる萌芽直後の 摘芽処理時の新芽再生力

凍霜害発生後の茶芽の再生は, 茶園の状態
によって時期や再生量に差が生じる現象が見 られる。このことは枝条活力の差が主な原因 と考えられている。そこで, 秋整枝面（樹冠 面）の母枝の異なる, 更新 2 年樹と更新 7 年 樹を用い, 秋整枝面から葉層 $5 \mathrm{~cm}$ 内の全ての 新芽を, 一番茶萌芽期直後に芽の基部から除 去し, 新芽の再生力を調查した。調查は, 再 萌芽後伸長した約 1 ケ月後に, 樹冠面より 1 $\mathrm{cm}$ 上の摘採機で摘採可能な芽(有効芽), 樹冠 
(茶研報92：33４1，2001)

表 3 更新経過年数と新芽除去後の再生芽数

$(n=3)$

\begin{tabular}{|c|c|c|c|c|c|c|c|c|c|c|}
\hline \multirow[b]{2}{*}{$\begin{array}{c}\text { 中切り更新後 } \\
\text { の経過年数 }\end{array}$} & \multirow[b]{2}{*}{ 母枝数 } & \multicolumn{3}{|c|}{ 効 芽 (本) } & \multirow[b]{2}{*}{$\begin{array}{c}\text { 対中切り } \\
7 \text { 年樹比 } \\
(\%)\end{array}$} & \multicolumn{3}{|c|}{ 無 効 芽 $\left(\right.$ 本 $\left./ \mathrm{m}^{2}\right)$} & \\
\hline & & $\begin{array}{l}\text { 葉層 } 5 \mathrm{~cm} \\
\text { 以内の母 } \\
\text { 枝加 } \\
\text { 再生芽数 }\end{array}$ & $\begin{array}{l}\text { 葉層 } 5 \mathrm{~cm} \\
\text { 以下の母 } \\
\text { 枝加らの } \\
\text { 再生芽数 }\end{array}$ & 計 & & $\begin{array}{l}\text { 葉層 } 5 \mathrm{~cm} \\
\text { 以内の母 } \\
\text { 枝加 } \\
\text { 再生芽数 }\end{array}$ & $\begin{array}{l}\text { 葉層 } 5 \mathrm{~cm} \\
\text { 以下の母 } \\
\text { 枝加らの } \\
\text { 再生芽数 }\end{array}$ & 計 & $\begin{array}{l}\text { 総新 } \\
\text { 芽数 }\end{array}$ & $\begin{array}{c}\text { 対中切 } \\
\eta 7 \text { 年 } \\
\text { 樹 比 } \\
(\%) \\
\end{array}$ \\
\hline 中切り 2 年樹 & 858 & 1,568 & 68 & 1,636 & 209 & 480 & 0 & 480 & 2,044 & $\overline{110}$ \\
\hline 中切り 7 年樹 & 890 & 758 & 25 & 783 & 100 & 1,075 & 8 & 1,083 & 1,866 & 100 \\
\hline 有 意 性 & NS & ** & NS & & & NS & & & NS & \\
\hline
\end{tabular}

注）調査：1996年 6 月 6 日・9日

有効芽：秋整枝面より $1 \mathrm{~cm}$ 上にのび摘採機で摘採可能な芽

無効芽：秋整枝面にあり摘採機で摘採不可の芽

有意性の検定：最小有意差法で行った。**（1％)

面にある摘採不可の芽 (無効芽) に区分して 行った。

2 年樹の新芽切除区は，再生した芽の形状 が大きく, 芽数も多く，7年樹の切除区に比 べ, 生葉収量は約 3 倍と多かった。7年樹の 再生した芽は小さく，芽数も極めて少なかっ た(表 2)。

樹冠面上の再生した新芽を調查した結果, 更新 2 年樹と更新 7 年樹では再生した総新芽 数に有意差を認めないが, 更新 2 年樹は有効 芽が多く，更新 7 年樹は弱小芽で無効芽が多 かった（表 3 )。

更新直後の茶樹は，枝条数は少ないが，芽 を除去しても再生した芽は大きかった。一方， 更新 7 年樹は,枝条数は多いが百芽重が軽く, 再生芽は摘採不可の弱小芽が多かった。この ことから, 中切り更新直後の茶樹は茶芽の再
生力, つまり「枝条活力」が強いと判断され る。更新 7 年樹は再生力が弱いことから, 更 新後は年次が進むに従って枝条活力が低下す ると考えられる。また，三番茶の摘採を中止 すると，新芽の形状が大きくなり生葉収量が 増加することから，樹勢維持のためには有効 と思われる。

\section{3 中切り更新初回樹の再生芽と仕立て4)}

3.1 中切り後の新枝条の生育

供試材は‘やぶきた’12年生 (1974年植栽) の 茶樹を, 処理は 5 月下旬に地上 $36 \mathrm{~cm}$ に初回の 中切り更新を行った。調查は処理後65日目の 再生芽で行い, 中切り後の母枝は365本 $/ \mathrm{m}^{2}$, 枝の切口面によって大 ( $10 \mathrm{~mm}$ 以上), 中（5 $\sim 9.9 \mathrm{~mm})$, 小 $(2 \sim 4.9 \mathrm{~mm})$, 細 $(2 \mathrm{~mm}$ 以 下）に区分した。そのグレード別の枝の割合

表 4 中切り更新（65日目）初回樹の母枝と新枝条

\begin{tabular}{|c|c|c|c|c|c|c|}
\hline \multirow{2}{*}{ 母枝のグレード } & \multirow[b]{2}{*}{$\begin{array}{c}\text { 母枝の枯死率 } \\
(\%)\end{array}$} & \multicolumn{3}{|c|}{ 再芽枝 条 数 } & 整 & 枝 \\
\hline & & $\begin{array}{c}\text { 分枝 数 } \\
\text { (本) }\end{array}$ & $\begin{array}{c}\text { 出芽位置 } \\
(\mathrm{cm})\end{array}$ & $\begin{array}{c}\text { 芽 長 } \\
(\mathrm{cm})\end{array}$ & $\begin{array}{c}\text { 整 枝数 } \\
\text { (本) }\end{array}$ & $\begin{array}{c}\text { 整 枝率 } \\
(\%)\end{array}$ \\
\hline 大 & 5 & 5.5 & -2.0 & 8.6 & 2.7 & 49.0 \\
\hline 中 & 5 & 6.2 & -3.1 & 6.5 & 2.0 & 32.3 \\
\hline 小 & 3 & 5.7 & -3.3 & 2.9 & 1.3 & 22.8 \\
\hline 細 & 53 & 3.0 & -3.1 & 2.8 & 1.0 & 33.3 \\
\hline 平 均 & 16 & 5.1 & -2.9 & 5.2 & 1.8 & 35.3 \\
\hline
\end{tabular}

注）中切り枝条の調查本数各グレード 40 本

調查1985年 大 $=10 \mathrm{~mm}$ 以上, 中 $=5 \sim 9.9 \mathrm{~mm}$, 小 $=2 \sim 4.9 \mathrm{~mm}$, 細 $=2 \mathrm{mm以下}$ 
は, 大 1 , 中 19 , 小 59 , 細 $20 \%$ であった。中 切り後の母枝の枯死率は, 強せん枝と乾燥等 の影響で大〜小は $3 〜 5 \%$ ，細は $53 \%$ と細い ほど多かった。

再生芽のせん除期（中切り後65日目）の母 枝 1 本当たりの新枝条数は，大～小が 5 本， 細は 3 本で大きいほど多く, 再生芽の主な出 芽位置は, 大がー $2 \mathrm{~cm}$, 中〜細はー $3 \mathrm{~cm}$ で, 大きいほど切り口面に近かった（表 4)。

再生芽の処理は, 更新面から+5 cmでせん 除と無せん除を行った。

秋整枝期（硬化期）の枝条数は，更新から 65日目の 7 月下旬の整枝時より増加したが， 整枝区は大が 8 , 中 6 ,小 6 , 細 2 本，無整 枝区は大が 6 , 中 8 , 小 7 , 細 2 本で処理の 差を認めなかった。

母枝 1 本当たりの枝数を見ると，翌年一番 茶を構成すると思われる有効枝は，無せん枝

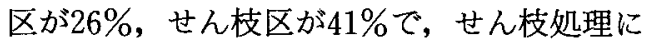
より増加した。また，無せん枝区は小や細の 枯れ枝が多かった。このことは, 遅く出芽し た弱小芽は生育旺盛な枝条の陰になったため と思われる。

このように，せん枝区は整枝を加えること で旺盛な枝条の生育が抑制され，弱小芽の生 育を促進したため，有効枝が増加したと考え
られた(表 5 )。芽数は中切り処理後 1,2 , 3 年目各茶期の摘採・整枝によって増加した。 3.2 中切り更新後の仕立て法

樹龄10年生（1974年植栽）の更新経歴のな いややぶきた’を用い，樹高 $84 \mathrm{~cm} 5$ 月下旬に $44 \mathrm{~cm}$ に中切り処理した。

再生芽の仕立て処理時期と程度は, 2 回仕 立ては 7 月上旬に中切り面より $+3 \mathrm{~cm}$ と+ $5 \mathrm{~cm}, 8$ 月上旬に $+1 \mathrm{~cm}, 1$ 回仕立てでは 7 月下旬に $+3 \mathrm{~cm}$ と $+5 \mathrm{~cm}, 8$ 月上旬に +5 $\mathrm{cm}$ と $+10 \mathrm{~cm}$ に区分し，せん除した。

春整枝処理は， 2 回仕立ての 7 月上旬 +3 $\mathrm{cm}$ と $+5 \mathrm{~cm}, 8$ 月上旬の $+1 \mathrm{~cm}, 1$ 回仕立 ての 7 月下旬の $+3 \mathrm{~cm},+5 \mathrm{~cm}$ は再生芽せ ん除位置から $+5 \mathrm{~cm} k, 1$ 回仕立ての 8 月上 旬の $+5 \mathrm{~cm}$ と $+10 \mathrm{~cm}$ 処理は $+3 \mathrm{~cm}$ に処理 した (表 6 )。

2 回仕立ては，期待した程に分枝数が少な く，枝条が細まり「芽の形状」が小さく，処 理 2 年目から劣る傾向を示し， 3 年目は明ら かに劣った。仕立ての程度は, 低仕立ては芽 の形状が小さ加った。高仕立ては処理翌年の 一番茶が芽数不足で更新処理による減収率が 高いが，二番茶以降 $2 ， 3$ 年目に芽数が増加 し $+10 \mathrm{~cm}$ 区が優った。高仕立ては百芽重が大 きく，摘採面を構成する枝条を太く維持でき

\section{表 5 硬化期の枝条数}

\begin{tabular}{cccccccc}
\hline 区 & $\begin{array}{c}\text { 母枝の } \\
\text { グレード }\end{array}$ & $\begin{array}{c}\text { 母枝 1 本当 } \\
\text { り枝数(本) }\end{array}$ & $\begin{array}{c}\text { 有効枝数 } \\
\text { (本) }\end{array}$ & $\begin{array}{c}\text { 有効枝率 } \\
(\%)\end{array}$ & $\begin{array}{c}\text { 無効枝数 } \\
(\%)\end{array}$ & $\begin{array}{c}\text { 無効枝率 } \\
(\%)\end{array}$ & $\begin{array}{c}\text { 母枝 1 本当たり } \\
\text { 枯枝率 }\end{array}$ \\
\hline & 大 & 8.2 & 4.5 & 54.9 & 3.3 & 40.2 & 4.3 \\
せ & 中 & 6.2 & 3.0 & 48.4 & 3.0 & 48.4 & 3.2 \\
枝 & 小 & 6.1 & 1.4 & 23.0 & 3.8 & 62.3 & 15.0 \\
区 & 細 & 2.0 & 0.1 & 5.0 & 1.4 & 70.0 & 25.0 \\
& 平 均 & 5.6 & 2.3 & 41.1 & 2.9 & 51.8 & 8.8 \\
\hline \multirow{2}{*}{ 無 } & 大 & 5.9 & 2.8 & 47.5 & 2.1 & 35.6 & 16.9 \\
中 & 8.2 & 2.4 & 29.3 & 4.5 & 54.9 & 17.1 \\
枝 & 小 & 6.6 & 0.9 & 13.6 & 4.5 & 68.2 & 18.2 \\
区 & 細 & 1.9 & 0.05 & 2.6 & 1.0 & 52.6 & 42.1 \\
& 平 均 & 5.7 & 1.5 & 26.3 & 3.0 & 52.6 & 19.3 \\
\hline
\end{tabular}

注）有效枝は中切り面より10〜 14cm内の枝条数 調查本数各グレード 20 本，母枝のグレードは表 4 に同じ 调查1985年 
（茶研報92：33〜41，2001）

表 6 試験区の構成

\begin{tabular}{|c|c|c|c|c|c|}
\hline & & 理 & 方 & & \\
\hline 試 験 区 & $\begin{array}{c}\text { 7月上旬 } \\
\text { ( } 7 \text { 月11日) }\end{array}$ & $\begin{array}{c}\text { 7月下旬 } \\
\text { ( } 7 \text { 月25日) }\end{array}$ & $\begin{array}{c}8 \text { 月上旬 } \\
(8 \text { 月 } 10 \text { 日) }\end{array}$ & $\begin{array}{c}\text { 春整枝 } \\
(3 \text { 月 } 9 \text { 日) }\end{array}$ & $\begin{array}{l}\text { 吏新当年に } \\
\text { 上がる樹高 }\end{array}$ \\
\hline 2 回仕立A区 & $O+3 \mathrm{~cm}$ & $\mathrm{~cm}$ & (O) $+1 \mathrm{~cm}$ & $+5 \mathrm{~cm}$ & $9 \mathrm{~cm}$ \\
\hline n $\quad \mathrm{B} 区$ & $O+5$ & & (O) +1 & +5 & 11 \\
\hline 1 回仕立A区 & & $O+3$ & & +5 & 8 \\
\hline B区 & & $O+5$ & & +5 & 10 \\
\hline C区 & & & $O+5$ & +3 & 8 \\
\hline " D区 & & & $O+10$ & +3 & 13 \\
\hline 無 処 理 区 & +1 & +1 & +1 & +2 & 5 \\
\hline
\end{tabular}

注) ○初回仕立 (O) 2 回目仕立

無処理は一〜三番茶摘採

数字は前回せん枝面からのせん除の高さ

表 7 処理 1 年目一番茶、茶芽の形態と収量

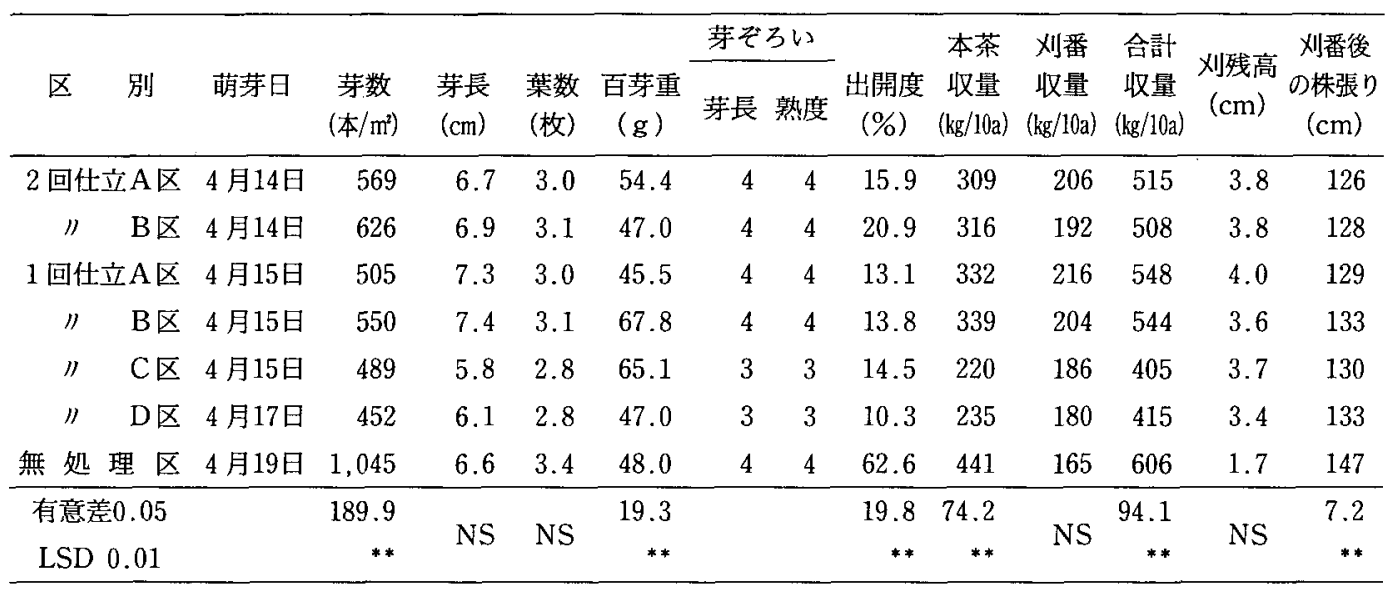

注）摘採日 5 月 14 日, 刈番 5 月 25 日

ると思われた。特に，7月下旬の 1 回仕立て十 $5 \mathrm{~cm}$ 如理翌年の減収率も少なく, 以後の収 量も安定していた（表 $6,7,8 ， 9$ )。

この結果, 初回の中切り更新後の仕立ては, 回数は 1 回，時期は新枝条が褐変し木化の始 まる 7 月下旬, 高さは側芽の充実した $+5 \mathrm{~cm}$ が良好と思われる。

中切り更新処理当年のせん枝は，生育旺盛 な枝条を抑制し, 弱小芽の生長を促し, 全体 の芽揃いを均一にすることが必要で，このた めのせん枝時期, 高さがポイントと思われる。 また, 茶芽の形態は, 百芽重, 芽長, 葉数は 中切り処理によって大きくなったが，その後
の摘採, 整枝で処理 3 年目は無処理と同程度 と小さくなった。

長崎県での中切り更新処理は, 一番茶摘採 直後に, 再生した新佾のせん除回数は 1 回, 時期は 7 月 25 日頃で, 仕立て回数が多いと「芽 の形状」が小さくなり, 更新後の維持が短く なると推定される。

宮崎県総合農業試験場茶業分場の成績7) （1981～1986）では, 中切り更新処理は早い ほど回復は早いが, 時期は 7 月20日までは可 能とし，新梢の最終せん除期は 8 月 10 日頃と 報告している。このことは管崎県と長崎県の 温度条件の差と思われる。すなわち, 茶芽の 
表 8 処理 2 年目一番茶、茶芽の形態と収量

\begin{tabular}{|c|c|c|c|c|c|c|c|c|c|c|c|c|}
\hline 別 & $\begin{array}{l}\text { 芽 数 } \\
\left(\text { 本 } / \mathrm{m}^{2}\right)\end{array}$ & $\begin{array}{c}\text { 芽 長 } \\
(\mathrm{cm})\end{array}$ & $\begin{array}{c}\text { 葉 数 } \\
\text { (枚) }\end{array}$ & $\begin{array}{c}\text { 百芽重 } \\
(\mathrm{g})\end{array}$ & $\begin{array}{c}\text { 出開度 } \\
(\%)\end{array}$ & $\begin{array}{r}\text { 本茶収量 } \\
(\mathrm{kg} / 10 \mathrm{a})\end{array}$ & $\begin{array}{l}\text { 刈番収量 } \\
(\mathrm{kg} / 10 \mathrm{a})\end{array}$ & $\begin{array}{l}\text { 合計収量 } \\
(\mathrm{kg} / 10 \mathrm{a})\end{array}$ & 芽ぞ & $\frac{\text { ろい }}{\text { 熟度 }}$ & $\begin{array}{c}\text { 刈残高 } \\
(\mathrm{cm})\end{array}$ & $\begin{array}{c}\text { 株張り } \\
(\mathrm{cm})\end{array}$ \\
\hline 2 回仕立A区 & 933 & 6.2 & 3.1 & 52.4 & 39.5 & 410 & 176 & 587 & 4.5 & 4.5 & 2.4 & 148 \\
\hline B区 & 878 & 5.3 & 3.0 & 63.8 & 37.8 & 404 & 156 & 560 & 4.5 & 4.5 & 2.3 & 150 \\
\hline 1 回仕立A区 & 907 & 6.2 & 3.2 & 50.6 & 48.5 & 395 & 143 & 538 & 4.3 & 4.5 & 2.4 & 150 \\
\hline B区 & 1,028 & 6.1 & 3.1 & 51.5 & 37.2 & 411 & 165 & 576 & 4.5 & 4.5 & 2.5 & 154 \\
\hline C区 & 957 & 7.1 & 3.4 & 57.5 & 36.0 & 429 & 151 & 580 & 4.5 & 4.5 & 2.3 & 150 \\
\hline D区 & 998 & 5.7 & 3.2 & 51.2 & 32.5 & 436 & 148 & 584 & 4.5 & 4.0 & 2.2 & 155 \\
\hline 無 好 理 区 & 1,071 & 5.7 & 3.2 & 53.0 & 63.4 & 518 & 219 & 737 & 4.5 & 4.0 & 2.2 & 162 \\
\hline $\begin{array}{l}\text { 有意差0.05 } \\
\text { LSD } 0.01\end{array}$ & NS & NS & NS & NS & $\begin{array}{r}25.2 \\
* *\end{array}$ & $\begin{array}{r}74.2 \\
* *\end{array}$ & NS & $\begin{array}{r}103.2 \\
* *\end{array}$ & & & NS & $\begin{array}{c}9.3 \\
* *\end{array}$ \\
\hline
\end{tabular}

注）萌芽日 4 月11日，摘採日 5 月 10 日，刈番 5 月 21 日

\section{表 9 処理 3 年目一番茶、茶芽の形驡と収量}

\begin{tabular}{|c|c|c|c|c|c|c|c|c|c|c|c|c|c|}
\hline \multirow{2}{*}{ 区別 } & \multirow{2}{*}{ 萌芽日 } & \multirow{2}{*}{$\begin{array}{c}\text { 芽数 } \\
\left(\text { 本 } / \mathrm{m}^{2}\right)\end{array}$} & \multirow{2}{*}{$\begin{array}{l}\text { 芽長 } \\
(\mathrm{cm}) \\
\end{array}$} & \multicolumn{3}{|c|}{ 葉数 百芽重 出開度 } & \multirow{2}{*}{$\begin{array}{l}\text { 本茶 } \\
\text { 収量 } \\
(\mathrm{kg} / 10 \mathrm{a})\end{array}$} & \multirow{2}{*}{$\begin{array}{c}\text { 刈番 } \\
\text { 収量 } \\
(\mathrm{kg} / 10 \mathrm{a})\end{array}$} & \multirow{2}{*}{$\begin{array}{l}\text { 合計 } \\
\text { 収量 } \\
\text { (kg/10a) }\end{array}$} & \multicolumn{2}{|c|}{ 芽ぞろい } & \multirow{2}{*}{$\begin{array}{l}\text { 刈残高 } \\
(\mathrm{cm})\end{array}$} & \multirow{2}{*}{$\begin{array}{r}\text { 株張り } \\
(\mathrm{cm})\end{array}$} \\
\hline & & & & (枚) & $(g)$ & $(\%)$ & & & & 芽長 & 熟度 & & \\
\hline 2 回仕立A区 & 4 月10日 & 1,568 & 5.8 & 3.3 & 40.4 & 65.2 & 486 & 169 & 655 & 4.2 & 4.3 & 1.3 & 164 \\
\hline B区 & $n$ & 1,356 & 4.8 & 3.1 & 44.5 & 58.2 & 501 & 184 & 685 & 4.5 & 4.5 & 1.2 & 164 \\
\hline 1 回仕立A区 & 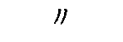 & 1,382 & 4.8 & 3.2 & 39.8 & 58.2 & 480 & 177 & 657 & 4.5 & 4.5 & 1.4 & 163 \\
\hline B区 & 4 月 8 日 & 1,619 & 4.2 & 3.0 & 40.7 & 62.4 & 533 & 207 & 740 & 4.5 & 4.5 & 1.4 & 169 \\
\hline C区 & $n$ & 1,439 & 5.3 & 3.2 & 43.3 & 57.7 & 538 & 159 & 698 & 4.5 & 4.5 & 1.5 & 166 \\
\hline D区 & $n$ & 1,522 & 5.9 & 3.4 & 42.9 & 61.9 & 581 & 155 & 735 & 4.5 & 4.5 & 1.5 & 167 \\
\hline 無 処 理 区 & 4 月11日 & 1,453 & 4.2 & 3.0 & 30.7 & 52.8 & 358 & 332 & 690 & 4.5 & 4.5 & 1.3 & 175 \\
\hline 有意差0.05 & & NS & 1.2 & > & 5.8 & & 69.6 & 101.3 & NS & & & $N$ & 6.1 \\
\hline LSD $\quad 0.01$ & & & * & & $* *$ & & ** & $* *$ & & & & N & $* *$ \\
\hline
\end{tabular}

注）摘採日 処理区 5 月 7 日，無処理区 5 月 5 日

生育は，地域の気象要因が大きく関与すると 考えられ, 生育ステージに適した処方が必要 である。近年は温暖化傾向で摘採期が早く, また，秋遅くまで生育する傾向にあり，樹勢 と地域の気象によっては，本県でも三番茶最 終せん除期は 8 月上旬も可能と思われる。

中切り更新処理が初めての茶樹での再生芽 のせん除処理は, 回数が多く,また, 程度が 低いと芽の形状が早く小さくなり, 更新の効 果持続が短いと判断され，再生した枝条をせ 几枝処理 (+5 cm) した効果は, 分枝の増加 は少ないが, 茶芽の芽揃いが良好となり, 摘 採できる有効芽が増加した。

\section{4 再更新法別による効果持続年数の検討 ${ }^{5)}$}

茶樹は，樹高調整や樹勢強化のため，植栽 後10年前後に更新処理を行うのが通常で, 更 新を行った茶樹も数年経過すると再更新が必 要である。そこで, 更新のサイクル技術を確 立するため,再更新効果持続年数を検討した。

1 回目の中切り更新を地上 $44 \mathrm{~cm}$ に処理し, 6 年経過した樹高 $88 \mathrm{~cm}$ の’やぶきた’を，一番 茶摘採後に浅刚り $-6 \mathrm{~cm}$, 潹刚り $-17 \mathrm{~cm}$, 中 切りは地上 $46 \mathrm{~cm}$ (前回中切り位置上 $+2 \mathrm{~cm}$ ) で再び処理した。浅侧り，深刈りは二番茶以 降に通常の摘採を, 中切りは再生芽のせん除 
を 7 月下旬に中切り面 $0 \mathrm{~cm}$ と $5 \mathrm{~cm}$ 上で行

い, その後の状況を調查した。

4. 1 浅刚りによる検討

生葉収量は処理前の $10 \mathrm{a}$ 当たり $600 \mathrm{~kg}$ に対 し， 2 年 (翌年) 目の一番茶は $110 \% ， 3$ 年目 は霜害を被り $85 \% ， 4$ 年目は $115 \%$ であった。 二番茶注好理 2 年目, 三番茶江処理 3 年目が 最高であった。製茶品質は茶芽が大きくなり 形状は劣ったが, 滋味, 香気が優った。株張 $\eta$, 葉層は処理当年秋に, 樹高は処理 2 年目 に更新前に戻った。

\section{2 深刚りによる検討}

生葉収量は処理前の $10 \mathrm{a}$ 当たり $620 \mathrm{~kg}$ に対 し， 2 年目の一番茶は芽数が減少し $72 \% ， 3$ 年目は $119 \% ， 4$ 年目は茶芽の形状が小さく $78 \%$, 製茶品質は各茶期とも外観が劣ったが 内質が優った。株張り, 葉層は処理当年秋に, 樹高は処理 4 年目に更新前に戻った。

\section{3 中切りによる検討}

生葉収量は処理前の $10 \mathrm{a}$ 当たり $560 \mathrm{~kg}$ に対 し， 2 年目の一番茶は芽数が少なく $72 \% ， 3$ 年目は $108 \% ， 4$ 年，5 年目は箱害で減収，6 年, 7 年目は防霜ファンが設置されたため 3 年目の収量を超えた。二番茶は茶芽の形状が 大きくなったが, 三番茶は更新の効果が小さ かった。株張りは処理 3 年目に，樹高は 7 年 目に更新前に戻った。再生芽のせん除 $0 \mathrm{~cm}$ (中切り面) は処理 2 年から茶芽の形状が小 さくなった。

更新処理程度が浅いと収量減は少なく，樹 高の㞔りは早いが，深いと逆になる。この試 験期間には霜害を度々被り, 生葉収量に一定

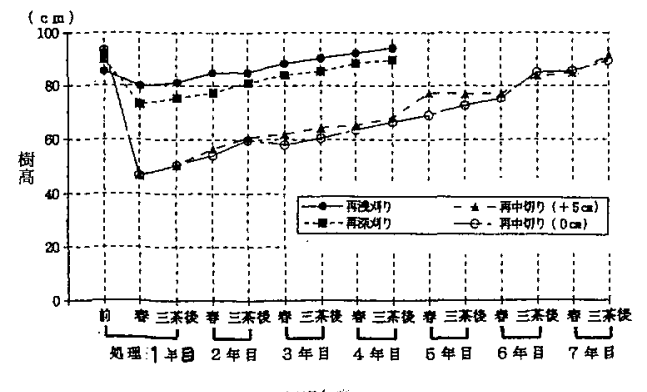

図 1 再更新法別樹高の推移
の傾向を示していない部分もあるが，総じて 年次の経過とともに茶芽の形状は小さくなっ た。製茶品質は, 茶芽の形状が大きいため外 観は劣るが，内質は向上する。この場合の摘 採は, 外観品質を考慮して浅摘みを行う必要 がある。茶樹の更新処理は, 処理後の早期回 復を図り収量減を最小にするために, 樹勢が 低下しないうちに行う方がよく，作業の関係 からも適正な樹高に維持する必要がある。

これらの結果, 中切り後の再更新の効果持 続年数は, 初回の更新後の効果持続年数と同 じ, 浅刚り 1 年, 深刚り 3 年, 中切り 6 年と 思われ, 大場 (1989) ${ }^{8)}$ と同椂の結果が得られ た(図 1，2)。また, 再中切り更新は, 初回 の中切り処理位置より $2 \mathrm{~cm}$ 上で行ったが, 再 生芽のせん除処理は, 更新面 $(0 \mathrm{~cm})$ が芽数 が増加した（図2)。

\section{5 二番茶後の更新処理と三番茶のせん除が 秋芽と翌年の茶芽に及ぼす影響6)}

1990年 5 月に樹齢17年生で再度中切り更新 を行い, その後更新 4 年樹（1994年）と 5 年 樹（1995年）の二番茶摘採後に浅刈り（樹冠 面から $-9 \mathrm{~cm})$ 抢よび深刚り $(-16 \mathrm{~cm})$ 更新 処理した区を設け,さらに, 三番茶不摘採, 三番茶摘採区と比較し，三番茶のせん除量と 秋整枝量预よび翌年一・二番茶の生育と生葉 収量について調查した。

中切り更新後 4,5 年目の三番茶芽と秋芽 生育期間に大干ばつ害を被ったことから，中 切り更新 4 年樹は, 三番茶不摘採区以外をせ

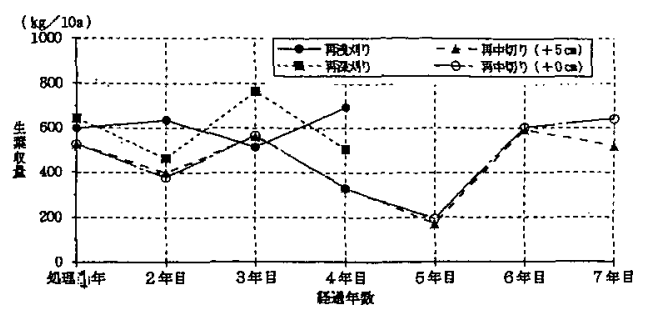

図2 再更新法別生葉収量の推移 (一番茶)

注）再中切りの 4 年目, 5 年目は凍霜害 
ん除したが，その量は少なく，秋芽の生育も 不良で整枝量も少なかった。しかし，翌年一 番茶の生葉収量は, 三番茶不摘採区および二 番茶後の更新区のいずれも, 百芽重が大きく， 特に更新処理区の生葉収量が多かった（表 10-1)。

一方，中切り更新 5 年樹は，干ばつの影響 で三番茶の芽伸びが不良と予想し，三蕃茶摘 採区以外はせん除を中止した。しかし，この 年は秋芽の生育期に前年より降雨が多く，秋 芽が過繁茂となり秋整枝量が多く, 翌年一番 茶に処理間の差がなく，更新効果は認められ なかった（表10-2）。

このことは，秋芽が伸び過ぎた茶園での秋 整枝処理の高さが，高いと芽数不足となるた め, 低くなり, 出芽力の弱い枝条の位置にな ることが原因と思われる。

\section{6 おわりに}

茶樹の枝条活力は, 更新後の経歴や肥培管 理技術等によって異なるが, 更新直後の茶樹 は枝条活力がある。その後, 摘採や整枝処理 の繰り返しにより次第に低下する。摘採中止 は価格調整や樹勢回復を目的に行われるが, 三番茶の摘採中止は茶芽の生育が旺盛となり 繁茂し，樹勢つまり「枝条活力」が向上する。 樹勢のある茶園では摘採を中止すると枝条が 伸びすぎ過繁茂となる。秋芽が伸び過ぎると 整枝の位置が翌年一番茶芽の出芽力の弱い部 位となり，一番茶の生葉収量, 茶品質が低下 する。このことから，秋芽枝条を過繁茂にし ない育成管理が必要である。

中切り更新後再生した新梢の仕立て処理 は，芽数が減少するため早期回復が必要であ る。低仕立ては枝条が早く細まり更新の効果

表10-1 二番茶後の更新処理と三番茶のせん除が秋整枝量および翌年一・二番茶に与える影響 $(n=2)$

\begin{tabular}{|c|c|c|c|c|c|c|c|c|c|c|c|c|c|}
\hline \multirow{3}{*}{ 処 } & \multirow{3}{*}{ 理 } & \multirow{2}{*}{\multicolumn{2}{|c|}{$\begin{array}{l}\text { 処理当年 (1994年) } \\
\text { 三番䒩甘ん俆量秋整枝量 }\end{array}$}} & \multicolumn{5}{|c|}{ 一番茶 (1995年) } & \multicolumn{5}{|c|}{ 二番茶 } \\
\hline & & & & \multirow[t]{2}{*}{ 摘採日 } & \multirow{2}{*}{$\begin{array}{c}\text { 百芽重 } \\
(\mathrm{g})\end{array}$} & \multirow{2}{*}{$\begin{array}{l}\text { 新芽数 } \\
\left(\text { 本 } / \mathrm{m}^{2}\right)\end{array}$} & \multirow{2}{*}{$\begin{array}{c}\text { 出開度 } \\
(\%)\end{array}$} & \multirow{2}{*}{$\begin{array}{l}\mathrm{E}_{\text {生葉収量 }} \\
(\mathrm{kg} / 10 \mathrm{a})\end{array}$} & \multirow[t]{2}{*}{ 摘採日 } & \multicolumn{3}{|c|}{ 百芽重新芽数出開度 } & \multirow{2}{*}{$\begin{array}{l}\text { 生葉収量 } \\
(\mathrm{kg} / 10 \mathrm{a})\end{array}$} \\
\hline & & $(\mathrm{kg} / 10 \mathrm{a})$ & $(\mathrm{kg} / 10 \mathrm{a})$ & & & & & & & $(g)$ & $\left(\right.$ 本 $\left./ \mathrm{m}^{2}\right)$ & $(\%)$ & \\
\hline \multicolumn{14}{|c|}{ 二番茶後更新处理区 } \\
\hline 浅刈口 & & 67 & 380 & 5 月 17 日 & 53 & 1,370 & 48 & 850 & 6 月29日 & 26 & 1,350 & 46 & 400 \\
\hline 深刈り & & 59 & 400 & " & 52 & 1,210 & 51 & 810 & " & 29 & 1,420 & 42 & 450 \\
\hline \multicolumn{14}{|c|}{ 二番余後页新排処理区 } \\
\hline 三番茶 & 摘採 & - & 150 & $\prime \prime$ & 41 & 1,670 & 59 & 720 & 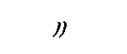 & 22 & 1,340 & 36 & 330 \\
\hline 三番茶 & & 90 & 100 & $n$ & 25 & 1,720 & 46 & 540 & m & 22 & 1,580 & 56 & 420 \\
\hline
\end{tabular}

注）茶樹は中切り 4 年目

表10-2 二番茶後の更新処理と三番茶のせん除が秋整枝量および翌年一・二番茶に与える影響 $(n=2)$ 処理当年 (1995年) 一番茶 (1996年) 二番茶

処 理 三番菜せ $几$ 除量秋整枝量 摘採日 百芽重 新芽数 出開度生葉收量 摘採日 百芽重新芽数出開度 生葉収量

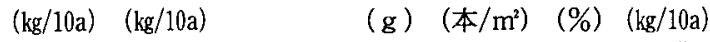

(g) $\left(\right.$ 本 $\left./ \mathrm{m}^{2}\right) \quad(\%) \quad(\mathrm{kg} / 10 \mathrm{a})$

\section{二番茶後更新处理区}

\begin{tabular}{|c|c|c|c|c|c|c|c|c|c|c|c|c|}
\hline 浅刈り & - & 880 & 5 月14日 & 30 & 1,300 & 46 & 550 & 6 月26日 & 30 & 1,600 & 76 & 480 \\
\hline 深刈り & - & 1,010 & 5 月17日 & 46 & 1,380 & 52 & 590 & 6 月26日 & 26 & 1,580 & 65 & 460 \\
\hline 莱後更新非処理区 & & & & & & & & & & & & \\
\hline 已番茶不摘採 & - & 420 & 5月11日 & 36 & 1,300 & 62 & 570 & 6 月21日 & 22 & 1,430 & 75 & 400 \\
\hline 三番茶摘採 & 170 & 290 & 5 月14日 & 29 & 2,170 & 81 & 560 & 6月26日 & 17 & 1.280 & 47 & 300 \\
\hline
\end{tabular}

注）茶樹は中切り 5 年目

干ばつ：1994, ’95年 
維持年数が短いと判断され, 高仕立ては芽数 の回復が遅れる。定植後初めての中切り更新 処理の仕立て回数は 1 回, 高さは更新面から $5 \mathrm{~cm}$ 上が処理翌年の減収率が少なく, 以後も 安定していた。また，再中切り更新処理は初 回更新処理位置より上でせん除するため, 再 生芽の仕立ての高さは, 更新面 $(0 \mathrm{~cm})$ が生 葉収量が優った。更新当年のせん枝処理は, 芽揃いを良くする効果が高く, 芽数は 2 年目 以降の摘採・整枝により增加した。

このように，摘採および整せん枝の回数や 処理程度は，茶樹の生育に影響が大きい。さ らに, 更新処理後の再生芽の整せん枝の回数 や時期・程度および最終せん除時期は，その 地域の気象を考慮する必要があり，樹勢の維 持向上は，枝条活力 (樹勢) が低下しないう ちに, 更新処理を計画的 (浅刚り 1 年, 深刈 り 3 年, 中切り 6 年) に行う必要がある。 なお, 本研究の推進にあたっては, 長崎県 総合農林試験場東彼杵茶業支場の関係研究 員, 臨時職員を始め, 今回のとりまとめには 森田 昭支場長に御協力いただいたここに 感謝の意を表する次第である。

\section{7 引用文 献}

1) 田中敏弘 (1992)：南九州における茶園の 整枝技術の改善, 茶研報, No.76, 73 80

2 ) 中野敬之 (1997)：二番茶の「みる芽」摘 みが翌年一番茶に及ぼす影響, 茶研報,

No.85 (別冊)，38～39

3 ）森山新三郎 (1995)：秋枝 (母枝) の形質 と新芽切除後の茶芽再生力との関係, 茶 研報, No.82 (別冊)，22～23

4 ）森山新三郎·馬㴊泰馬・龍野二郎 (1987)： 茶の中切り更新技術の確立, 長崎総農林 試研報 (農業部門)，No.15，141～153

5 ）森山新三郎 (1996)：茶樹中切り後の更新 効果の持続年数, 茶研報, No.84 (別冊), $14 \sim 15$

6 ）森山新三郎・㴊 通則 (1999)：三番茶摘 採の有無が秋芽の生育と翌年一番茶に及 涩影響, 茶研報, No.87, $1 \sim 6$

7 ) 宮崎県総合農業試験場茶業支場 （1981～1986）：中切り更新試験, 昭和61 年度試験成績書, $17 \sim 23$

8 ）大場正明(1989)：茶樹の更新方法とその 後の生育収量および品質への影響, 静岡 県茶試研報, No.14, 11 16 